
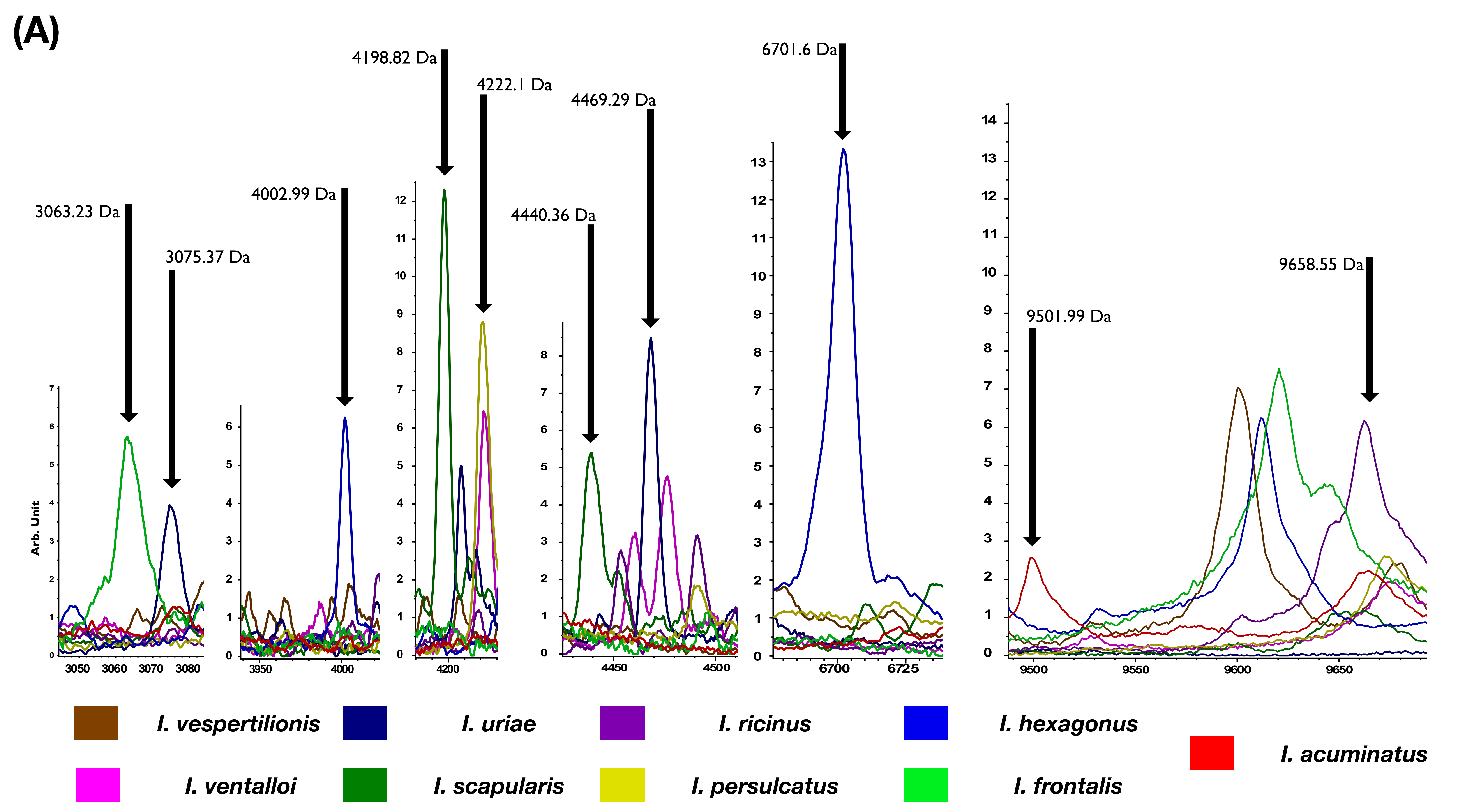

\title{
I. vespertilionis
}

I. uriae

I. ricinus

I. hexagonus

I. ventalloi

I. scapularis

I. persulcatus

I. frontalis 
